\title{
GENETIC COLLECTION OF OLEIC ACID CONTENT IN SUNFLOWER SEED OIL
}

\author{
Demurin, Y. ${ }^{*}$ and Borisenko, O.
}

All Russia Research Institute of Oil Crops (VNIIMK), 350038 Filatova 17, Krasnodar, Russia

Received: November 15, 2011 Accepted: December 10, 2011

SUMMARY

Development of genetic collection is considered to be an essential part of genetic resources of cultivated sunflower. The VNIIMK genetic collection of identified alleles determining oleic acid content in the seed oil consists of about 50 constant inbred lines. Fourteen of them are in a core collection. The general range of this trait varies from 20 to $92 \%$. These inbred lines correspond to four main phenotypic classes: low, conventional, mid and high oleic. The normal line RIL 100 was shown to contain a high oleic mutation $\mathrm{Ol}$ in hypostatic condition. The mid oleic LG27 averagely $67 \%$ does not contain the high oleic mutation in genetic background. The high oleic LG 26 with relatively low content of oleic acid, about $86 \%$, possesses resistance to suppressor's actions.

Key words: fatty acid composition, mutation, gene, suppressor

\section{INTRODUCTION}

The genetic collection of identified alleles determining a character is the permanent result of screening for genetic variability, inheritance analysis and allelic test with environment influence control (Fernandez-Martinez et al., 2009; Seiler and Jan, 2010; Vear, 2010). The clear correspondence between genotype and phenotype is believed to be a goal.

Oleic acid content belongs to the main characteristics of the seed oil quality. There were many attempts to carry out the genetic research with this trait. The most of them were dedicated to a high oleic mutation of variety Pervenets, obtained by Soldatov (1976). There are data of another mutant line with $80 \%$ of oleic acid content from Bulgaria (Ivanov, P. and Ivanov, I., 1982) and a mutant genotype with up to $90 \%$ of oleic acid content from Italy (Andrich et al., 1992). Nevertheless, Pervenets was exclusively used as a donor of the high oleic trait in breeding programs worldwide.

* Corresponding author: e-mail: yakdemurin@yandex.ru 
Research on genetic control of a high oleic mutation led to the hypotheses of one dominant gene $\mathrm{Ol}$ (Fick, 1984; Urie, 1985), major gene $\mathrm{Ol}$ and gene-modifier $\mathrm{ml}$ (Miller et al., 1987), recessive gene ol and dominant Ml (Fernandez et al., 1999), three complementary genes Ol1, Ol2 and Ol3 (Fernandez-Martinez et al., 1989), five genes Ol1, Ol2, Ol3, Ol4 and Ol5 (Velasco et al., 2000), gene $\mathrm{Ol}$ with incomplete penetrance determined by genotypic epistatic factors of reversion (Demurin et al., 1996; Demurin, 2003), high oleic locus oleHOS and suppressor locus Sup (Lacombe et al., 2001; Berville, 2010). All of these hypotheses focus on explanation of the lack of mutant seeds from a monogenic number expected in the progenies of cross-breeding mutant with normal lines.

This paper describes the results of research which have been obtained since 1982 at VNIIMK in order to develop the genetic collection of sunflower for oleic acid content in the seed oil.

\section{MATERIALS AND METHODS}

Constant inbred lines of the genetic collection were involved in the research. It includes both lines developed at VNIIMK and the lines from other institutions. The next designations of the lines are used: VK (VNIIMK, Krasnodar) and LG (line genetic) - from VNIIMK; $\mathrm{K}$ - from VIR; HA and RHA - from USDA; RIL (recombinant inbred line) - from INRA.

The plants were grown, self-pollinated or crossed in the field plots of VNIIMK, Krasnodar during summer time at $70 \times 35 \mathrm{~cm}$ population density. Greenhouse chambers were used in winter annually.

Fatty acid composition of the oil from the seeds was determined by gas chromatography of methyl esters.

\section{RESULTS AND DISCUSSION}

There are about 50 constant inbred lines of sunflower in the VNIIMK collection regarding oleic acid content in the seed oil. The general range of this trait varies from 20 to $92 \%$ in Krasnodar weather conditions at $45^{\circ}$ northern latitude with average temperature of $27^{\circ} \mathrm{C}$ in July. At that time seed maturation usually begins. The range can be divided into four main phenotypic classes: low, conventional, mid (increased) and high oleic (Figure 1). Two gaps surrounding a mid oleic class have no inbred lines with corresponding phenotypes.

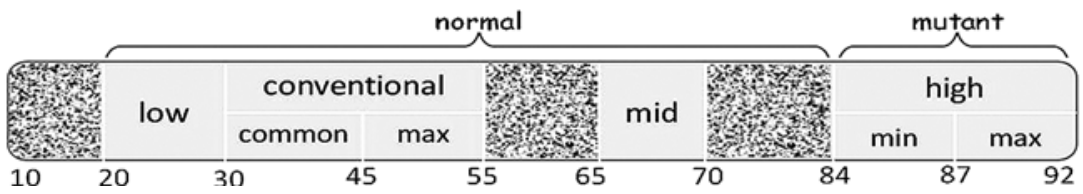

Figure 1: Oleic acid classes of homozygous genotypes (\%) 
A low oleic class from 20 to $30 \%$ includes two lines. LG 28 is originated from selfed progenies of the old VNIIMK open pollinated variety of Kruglik A-41. Another one of RHA 413 was developed in the USDA, ND, Fargo.

A conventional oleic class from 30 to $55 \%$ can be divided into common and maximum subclasses. The first is abundant with dozens of lines. The most interesting representative of that is RIL $100(83 \mathrm{HR} 4 \times$ RHA 345) which was created in the frame of a research program of INRA, France. RIL 100 possesses a normal phenotype of oleic content, while the molecular marker shows an existence of the high oleic mutation. French geneticists have tried to explain this phenomenon by probable action of a suppressor (Berville, 2010). We have carried out an inheritance analysis in Krasnodar, VNIIMK with the cross-breeding of LG $28 \times$ RIL 100. Parents and $F_{1}$ were normal in oleic acid content of 27,40 and $32 \%$ respectively. The $F_{2}$ seeds segregated in two classes of 111 normal: 9 high oleic. The high oleic mutant segregants in the $\mathrm{F}_{2}$ from the cross of phenotypic normal lines are a crucial evidence of suppression over $\mathrm{Ol}$ mutation obtained for the first time with classical hybridological approach. The dominant epistatic action of the suppressor as a major gene might be proposed on the data obtained.

There are two lines possessing from 45 to $55 \%$ of oleic content near a maximum border of the conventional class. It is interesting to note that these $\mathrm{K} 1587$ and VK 678 belong to early maturing genotypes (Table 1). As a result the sunflower genes of early flowering can indirectly influence fatty acid composition in the way of increasing oleic content in the oil due to the higher temperature during seed maturation.

Table 1: Core genetic collection for oleic acid content in sunflower seed oil

\begin{tabular}{|c|c|c|c|c|}
\hline \multicolumn{2}{|c|}{ Phenotype } & \multirow[b]{2}{*}{ Line } & \multirow[b]{2}{*}{ Genotype } & \multirow{2}{*}{$\begin{array}{l}\text { Period from emergence } \\
\text { to flowering, days }\end{array}$} \\
\hline class & $\begin{array}{c}\text { average oleic } \\
\text { acid content, } \%\end{array}$ & & & \\
\hline \multirow{3}{*}{ High oleic } & 91 & VK 508 & $\mathrm{OIOI}$ & 51 \\
\hline & 89 & VK 876 & $\mathrm{OIOI}$ & 55 \\
\hline & 86 & LG 26 & $\mathrm{OIOI}+$ Sup-resistance & 50 \\
\hline \multirow{2}{*}{ Mid oleic } & 69 & VK 805 & OIOI p1p1p2p2 & 50 \\
\hline & 67 & LG 27 & olol + additive genes & 53 \\
\hline \multirow{7}{*}{ Conventional } & 53 & K 1587 & olol SupSup & 47 \\
\hline & 45 & VK 678 & olol & 48 \\
\hline & 41 & RIL 100 & OIOI SupSup & 53 \\
\hline & 40 & K 235 & olol SupSup & 48 \\
\hline & 40 & K 824 & olol SupSup & 55 \\
\hline & 35 & VK 580 & olol & 50 \\
\hline & 34 & RHA 416 & olol SupSup & 51 \\
\hline \multirow{2}{*}{ Low oleic } & 29 & HA 413 & olol & 53 \\
\hline & 27 & LG 28 & olol & 61 \\
\hline
\end{tabular}


A mid oleic class from 65 to $70 \%$ contains only one line without the high oleic mutation $\mathrm{Ol}$ in its genotype (Table 1). LG 27 is originated from selfed progenies of the K 2210 accession of VIR. This trait is controlled by additive genes with strong maternal influence in the $F_{1}$ (unpublished data) though in the cross-breeding with a high oleic line it seemed to be recessive monogenic (Demurin et al., 2000). Another possibility to get the mid oleic phenotype was realized in VK 805 with a partial epistatic effect of a high palmitic mutation over a high oleic one in a combined homozygote genotype (Table 2). That phenomenon was firstly described by FernandezMartinez et al. (1997). Moreover, several mid-range oleic acid genetic stocks released by Miller and Vick (2002) are based on the high oleic mutation background.

Table 2: Mid oleic phenotype of high palmitic/ high oleic mutations combined

\begin{tabular}{lccccc}
\hline \multirow{2}{*}{ Line } & \multicolumn{5}{c}{ Fatty acid composition, \% } \\
\cline { 2 - 6 } & $\mathrm{C} 16: 0$ & $\mathrm{C} 16: 1$ & $\mathrm{C} 18: 0$ & $\mathrm{C} 18: 1$ & $\mathrm{C} 18: 2$ \\
\hline VK 805 OI, $p$ & 18.5 & 5.5 & 1.4 & 69.0 & 5.6 \\
VK 580 wild type & 5.7 & trace & 3.0 & 35.1 & 56.2 \\
\hline LSD $_{05}$ & 1.1 & - & 0.5 & 2.0 & 1.5 \\
\hline
\end{tabular}

A high oleic class from 84 to $92 \%$ consists of two subclasses. LG 26 is located within the first one with minimum oleic content (Table 1). This line shows resistance to suppressor with complete dominance of $\mathrm{Ol}$ mutation in the $\mathrm{F}_{1}$ and monogenic inheritance in the $\mathrm{F}_{2}$ when LG 26 was crossed with suppressor-carrying lines (unpublished data). VK 876 and VK 508 have maximum level of oleic acid content up to $91 \%$.

\section{CONCLUSIONS}

The VNIIMK genetic collection of identified alleles determining oleic acid content in sunflower seed oil consists of about 50 constant inbred lines ( 14 of them in a core collection). The general range of this trait varies from 20 to $92 \%$. These inbred lines correspond to four main phenotypic classes: low, conventional, mid and high oleic.

\section{ACKNOWLEDGEMENTS}

This work was supported by grant 09-04-96588 from the Russian Foundation of Basic Research (RFBR); grant 11-04-96522 and grant 11-04-96524 from VNIIMK in the frame of regional competition of RFBR. 


\section{REFERENCES}

Andrich, G., Balzini, S., Zinnai, A., Fiorentini, R., Baroncelli, S., Pugliesi, C., 1992. The oleic/ linoleic ratio in achenes coming from sunflower lines treated with hard X-rays. In: Proc. $13^{\text {th }}$ Int. Sunflower Conf., Pisa, Italy, pp. 1544-1549.

Berville, A., 2010. Oil composition variations. In: Genetics, genomics and breeding of sunflower, $\mathrm{Hu}$, J., Seiler, G. and Kole, C. (Eds.), Science Publisher, pp. 253-277.

Demurin, Ya., 2003. Up-to-date results on biochemical genetics of sunflower in VNIIMK. Helia 26(38): 137-141.

Demurin, Ya., Škorić, D., 1996. Unstable expression of $O l$ gene for high oleic acid content in sunflower seeds. In: Proc. $14^{\text {th }}$ International Sunflower Conference, Beijing/Shenyang, 12-20 June 1996, China, pp. 145-150.

Demurin, Ya., Škorić, D., Verešbaranji, I., Jocić, S., 2000. Inheritance of increased oleic acid content in sunflower seed oil. Helia 23(32): 87-92.

Fernandez, H., Baldini, M., Olivieri, A.M., 1999. Inheritance of oleic acid content in sunflower oil. J. Genet. \& Breed. 53: 99-103.

Fernandez-Martinez, J.M., Perez-Vich, B., Velasco, L., 2009. Sunflower. In: Oil Crops, Handbook of Plant Breeding, V.4, Vollmann, J. and Rajcan, I. (Eds.), Springer, pp. 155- 232.

Fernandez-Martinez, J., Jimenez, A., Dominguez, J., Garcia, J.M., Garces, R., Mancha, M., 1989. Genetic analysis of the high oleic acid content in cultivated sunflower. Euphytica 41: 39-51.

Fernandez-Martinez, J., Mancha, M., Osorio, J., Garces, R., 1997. Sunflower mutant containing high levels of palmitic acid in high oleic background. Euphytica 97: 113-116.

Fick, G.N., 1984. Inheritance of high oleic acid in the seed oil of sunflower. Proc. Sunflower Res. Workshop, National Sunflower Association, Bismarck, ND, p. 9.

Ivanov, P., Ivanov, I., 1982. Biochemical characteristics of several sunflower muntants. In: Proc. $30^{\text {th }}$ Anniversary of Institute "Dobroudja", Sofia, Bulgaria, pp. 98-102.

Lacombe, S., Kaan, F., Leger, S., Berville, A., 2001. An oleat desaturase and a suppressor loci direct high oleic acid content of sunflower (Helianthus annuus L.) oil in the Pervenets mutant. Life Sciences (Paris) 324: 1-7.

Miller, J.F., Zimmerman, D.C., Vick, B.A., 1987. Genetic control of high oleic acid content in sunflower oil. Crop Science 27(5): 923-926.

Miller, J.F., Vick, B.A., 2002. Registration of four mid-range oleic acid sunflower genetic stocks. Crop Science 42(3): 994.

Seiler, G., Jan, C.C., 2010. Basic information. In: Genetics, genomics and breeding of sunflower, Hu, J., Seiler, G. and Kole, C., Science Publisher, pp. 1-50.

Soldatov, K.I., 1976. Chemical mutagenesis in sunflower breeding. In: Proc. $7^{\text {th }}$ Int. Sunflower Conf., Krasnodar, USSR, pp. 352-357.

Urie, A.L., 1985. Inheritance of high oleic acid in sunflower. Crop Sci. 25(6): 986-989.

Vear, F., 2010. Classic genetics and breeding. In: Genetics, genomics and breeding of sunflower, Hu, J., Seiler, G. and Kole, C. (Eds.), Science Publisher, pp. 51-77.

Velasco, L., Perez-Vich, B., Fernandez-Martinez, J.M., 2000 Inheritance of oleic acid content under controlled environment. In: Proc. $15^{\text {th }}$ Int. Sunflower Conf., 12-15 June 2000, Toulouse, France: A31-A36. 
